\title{
Correction to: Gene overexpression screen for chromosome instability in yeast primarily identifies cell cycle progression genes
}

\author{
Hanna Tutaj ${ }^{1}$ - Elzbieta Pogoda ${ }^{1} \cdot$ Katarzyna Tomala $^{1} \cdot$ Ryszard Korona $^{1}$
}

Published online: 16 October 2018

(c) Springer-Verlag GmbH Germany, part of Springer Nature 2018

\section{Correction to: Current Genetics}

https://doi.org/10.1007/s00294-018-0885-x

In the original publication, 'Frumkin JP et al.' reference was missed to include in the reference list. The complete reference should read as below.

Frumkin JP et al (2016) The interplay between chromosome stability and cell cycle control explored through gene-gene interaction and computational simulation. Nucleic Acids Res 44:8073-8085. 